\title{
岩盤上土層表面における弾性変位について* \\ SURFACE DISPLACEMENT OF SOIL-ROCK SYSTEMS UNDER \\ UNIFORMLY DISTRIBUTED LOADS
}

\section{1. 緒言}

半無限弾性体の表面に鉛直荷重が加えられたときの応 力と変位の問題は Boussinesq ${ }^{1)}$ によって解かれ, その 結果は土質力学においてきわめて広く利用されている。

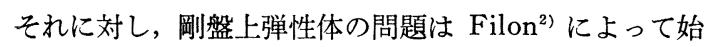
めて扱われ, その後 $\mathrm{Melan}^{3)}, \mathrm{Marguerre}{ }^{4)}, \mathrm{Biot}^{5)}$, Pickett $^{6)}$ らにより同様の問題の種々の場合が扱われた が,これらはいずれも剛盤上に生ずる応力の值に注目し た研究であった。

剛盤上弾性体の表面沈下をはじめて扱ったのは Steinbrenner ${ }^{7)}$ であるが，彼は Boussinesq の解を利用した 近似式を示し，この式が Terzaghi の Theoretical Soil Mechanics に紹介されたので一般によく知られ, 岩盤上 土層表面の弾性的沈下を知るためにもっぱら用いられて きた。最近の重要な研究として, Burmister ${ }^{8)}$ が剛盤上 弾性体の忘力と変位について多くの厳密解を示したが, 彼の行なった計算は長方形等分布載荷の場合で, 弾性体 のポアソン比が 0.2 と 0.4 の場合に限られている。そ の後, $\mathrm{Mandel}^{9}$, Sovinc ${ }^{10)}$ もこの問題の変位に関する 計算を行なっている。

しかし, 上述の従来の研究結果のみでは, 岩盤 上土層表面の弾性的沈下に関して, Steinbrenner の近似式にとってかわるに十分な厳密解が求めら れておらず, Steinbrenner 近似式の精度を十分検 討することもできない。そこで，筆者らはポアソ ン比が 0 から 0.5 の範囲に対し, また円形等分 布荷重, 帯状等分布荷重, 長方形等分布荷重に対 し，また岩盤一土層接面の粗滑の異なる境界条件 に対し計算し, 種々の場合を図表化し，この問題 の理論的傾向を調べ，また Steinbrenner の近似 解との比較を行なった。

またこの問題で, 下層がある程度圧縮性のある

*この研究の詳細は American Society of Civil Engineering の Soil Mechanics and Foundations Division 投稿中であるがそれを和文にて要約したものが本報文であ る。また，本報文の前半については第 1 回土質工学研究発 表会18亿て紹介した。

** 正会員 工博 名古屋大学助教授 工学部土木工学科

*** Ph. D., D. Sc. Dean, Nova Scotia Technical College, Halifax, Nova Scotia, Canada.

\author{
植 下 協**・G.G. マイヤホフ*** \\ By Kano Ueshita and G.G. Meyerhof
}

二層系と考えた場合の表面変位量についても解析し, 剛 盤上弾性体の場合の結果と比較した。

\section{2. 剛盤上弾性体の表面変位}

\section{（1）変位影響值の定義}

一般に剛盤上弾性体表面の鉛直変位 $w$ は弾性論によ りつぎのように表わしうる。

$$
w=(p / E) B I \text {. }
$$

ここに, $p:$ 荷重強度

$E:$ 弾性体の弾性係数

$B$ : 載荷面の幅（または載荷面の大きさを表わすあ る值)

\section{$I:$ 変位影響值}

このIは弾性理論により, 弾性体のポアソン比, 弾性 体の層厚 $T$ と $B$ との比, 載荷面の形状, 二層間接面の 条件等できまるものである。

\section{（2） 円形等分布荷重の場合の変位影響値}

剛盤上弾性表面に円形等分布荷重が加わったときの中 心点における変位影響值 $I_{c o}$ をLGP-30 および HITAC5020 電子計算機で計算した。この場合の変位影響值 $I_{c o}$ はつぎのように定義される。

\section{図一1 円形等分布荷重による岩盤上土属表面の弾性沈下}

$\begin{array}{ll}\text { （a）剛盤上弾性体表面の変位 } & \text { (b) 二層弾性体表面の变位 }\end{array}$
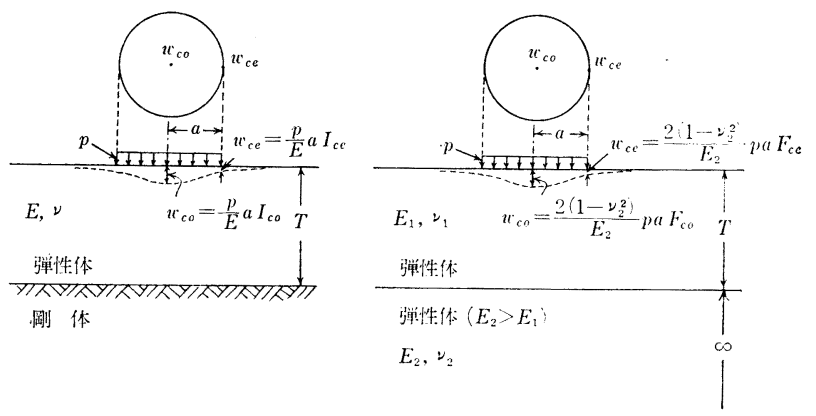

$$
I_{c o}=w_{c o} / \frac{p}{E} a=f(T / a, \nu, \text { 接面の条件 }) \cdots(2)
$$

ここに, $w_{c 0}$ : 円形等分布荷重の中心点における変位 (図-1 参照)

$a:$ 円形等分布荷重の半径

図一2 は二層接面が粘着性の場合を仮定し, ポアンン 比 をパラメーターとして, 厚さ係数 $T / a$ と変位影響 


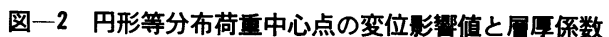
（粘着接面の場合）

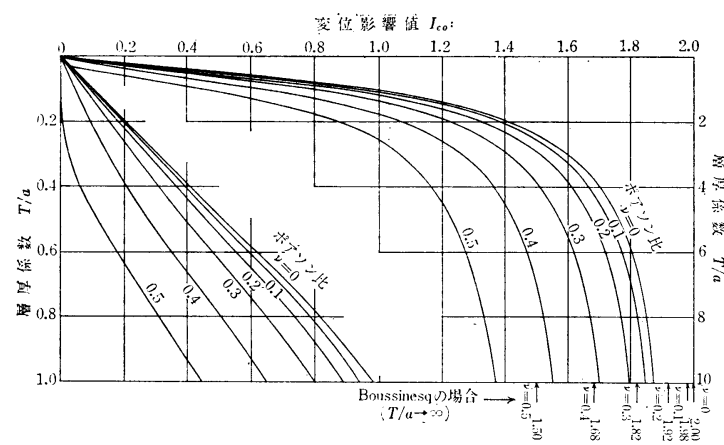

值 $I_{c o}$ との関係を示している。これらの曲線は $T / a$ が 増大すると Boussinesq の関倸，すなわち

$$
I_{c o}=2\left(1-\nu^{2}\right)
$$

に近づく。

\section{（3）帯状等分布荷重の場合の变位影響値}

帯状等分布荷重の中央点に対する変位影響值 $I_{s o}$ はつ ぎのように定義される。

$$
I_{s o}=w_{s o} / \frac{p}{E} b=f(T / b, \nu, \text { 接面の条件 }) \text {. }
$$

ここに, $w_{s o}$ ：帯状等分布荷重の中央点における変位 (図-3 (a) 参照)

この $I_{s o}$ を接面が粘着性の場合と滑動性の場合の両条 件で LGP-30 電子計算機により計算した。その結果か らつぎに定義される帯状荷重隅角部の変位影響值 $I_{s c}$ を

\section{図一3带状等分布荷重による岩盤上土局} 表面の弾性沈下

(a) 中心点の変位

（b）隅角点の変位
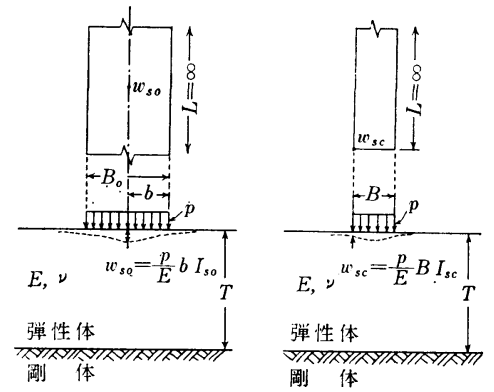

\section{図一4帯状等分布荷重隅角点の変位狸锌值と 扈厚係数の関係}

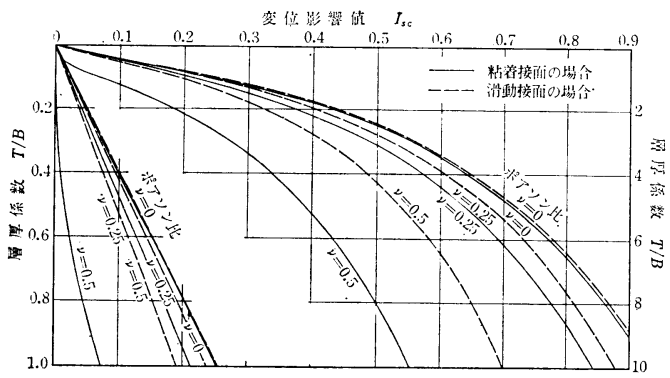

重ね合せの原理で求めた。

$$
I_{s c}=w_{s c} / \frac{p}{E} B=f(T / B, \nu, \text { 接面の条件 }) \cdots
$$

ここに, $w_{s c}$ : 帯状等分布荷重の隅角部における変位 （図一3 (b) 参照)

$I_{s c}$ についての計算結果を 図一4 に示す。図一4 によ れば，変位影響值におよぼすポアソン比と接面条件の影. 響は $\nu=0.5$ 付近において顕著であるが， $\nu=0$ 付近で は微小である。

\section{（4）長方形等分布荷重の場合の変位影響值}

長方形等分布荷重隅角点に対する変位影響值 $I_{r c}$ はつ. ぎのように定義される。

$$
I_{r c}=w_{r c} / \frac{p}{E} B=f(T / B, L / B, \nu, \text { 接面の条件 })
$$

ここに, $w_{r c}$ : 長方形等分布荷重の隅角部における変 位 (図一5 参照)

$B:$ 長方形載荷面の幅

$L:$ 長方形載荷面の長さ

$I_{r c}$ については，円形等分布荷重についての計算をも とに図解により求めた。その結果を各ポアソン比別に 図一6 (a), (b), (c), (d), (e), (f) に示した。これらの. 曲線は $T / B$ が無限大において Boussinesq 理論にもと ゔく次式の值となる。

$$
I_{r c}=\frac{\left(1-\nu^{2}\right)}{\pi}\left[\lambda \log _{e} \frac{1+\sqrt{\lambda^{2}+1}}{\lambda}+\log _{e}\left(\lambda+\sqrt{\lambda^{2}+1}\right)\right]
$$

$$
\text { ここに, } \lambda: L / B
$$

なお Steinbrenner ${ }^{7)}$ は剛盤上弾性体表面の長方形分 布荷重隅角点の変位影響值の近似值をつぎのように与え た。

$$
\begin{aligned}
I_{r c}= & \left(1-\nu^{2}\right) I_{1}+\left(1-\nu-2 \nu^{2}\right) I_{2} \\
I_{1}= & \frac{1}{\pi}\left[\lambda \log _{e} \frac{\left(1+\sqrt{\lambda^{2}+1}\right) \sqrt{\lambda^{2}+\delta_{B}^{2}}}{\lambda\left(1+\sqrt{\left.\lambda^{2}+\delta_{B}^{2}+1\right)}\right.}\right. \\
& \left.+\log _{e} \frac{\left(\lambda+\sqrt{\lambda^{2}+1}\right) \sqrt{1+\delta_{B}{ }^{2}}}{\lambda+\sqrt{\lambda^{2}+\delta_{B}{ }^{2}+1}}\right] \\
I_{2}= & \frac{\delta_{B}}{2 \pi} \tan ^{-1} \frac{\lambda}{\delta_{B} \sqrt{\lambda^{2}+\delta_{B}^{2}+1}}
\end{aligned}
$$
土居表面の弾性沈下

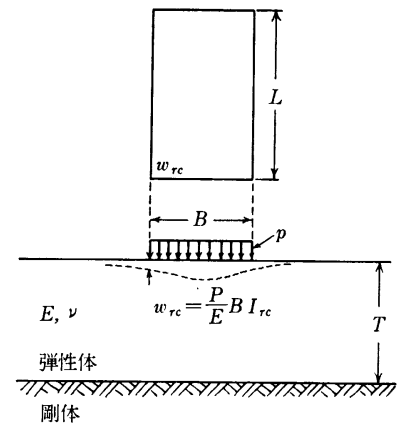


図一6（a）長方形等分布荷重隅角点の变位影部值と 局医係数の間係（ポアソン比 0.5 , 粘着 接面の場合)

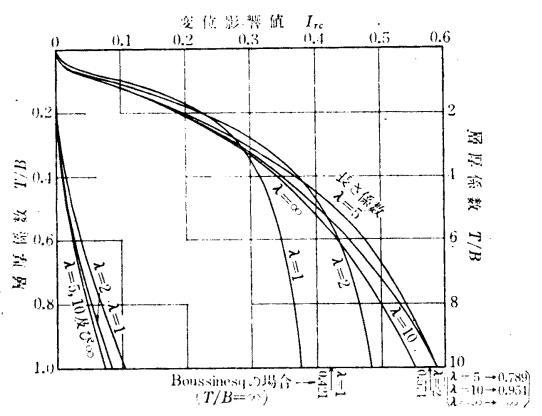

図一6（b）長方形等分布荷重隅角点の变位影籍值と 目厚係数の関係（ポフソン比 0.4 , 粘着 接面の場合)

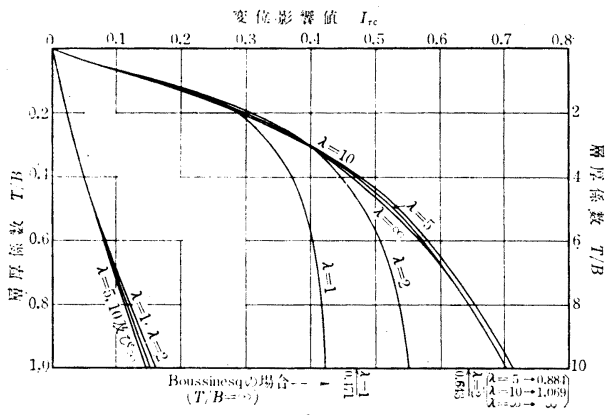

図一6（c）長方形等分布荷直隅角点の変位影策值と

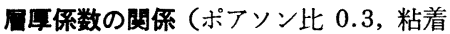
接面の場合）

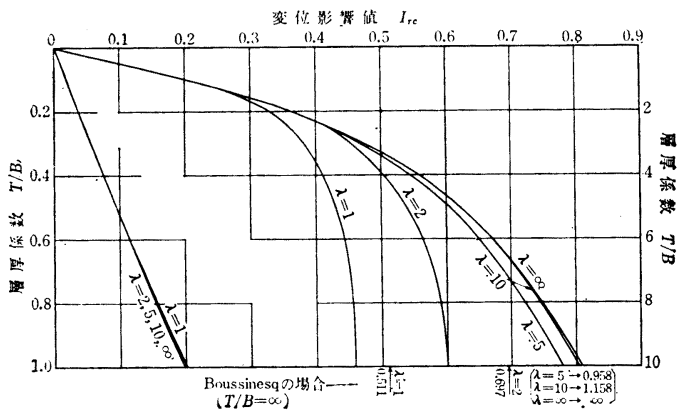

図一6 (d) 長方形等分布荷重隅角点の变位影嘞值と 目厚係数の関係（ポアソン比 0.2 , 粘着 接面の場合）

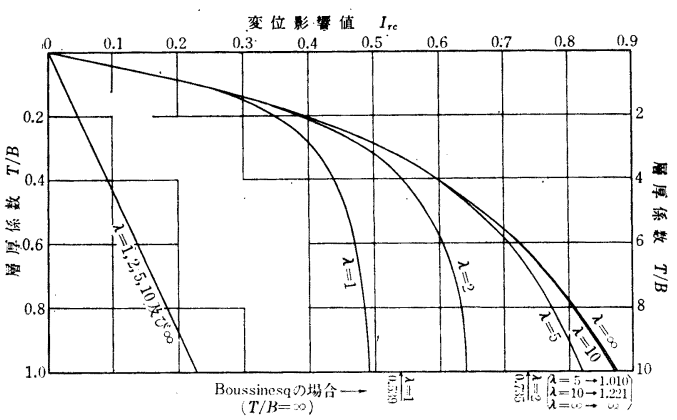

図一6（e）長方形等分布荷重隅角点の変位坛签值と 用平保数の関係（ポアソン比 0.1 , 粘着 接面の場合)

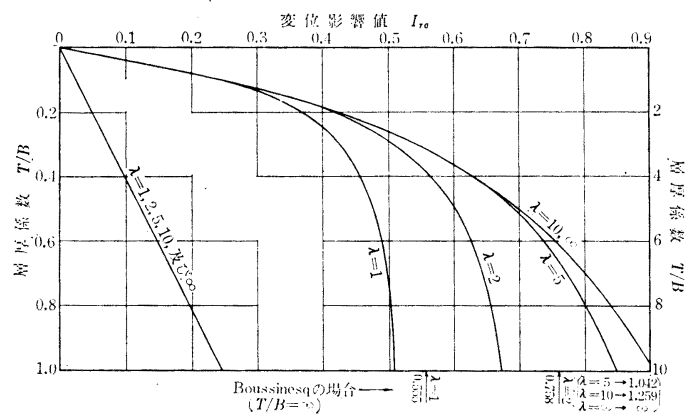

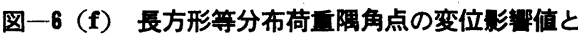
回厚保数の䦕係（ポアソン比 0 , 粘着接 面の場合)

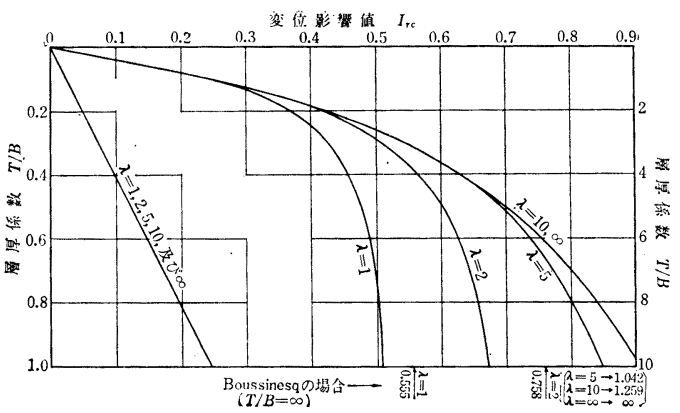


図一7長方形等分布荷重隅角点の変位影晦值と届厚係数と の関係における Eteinbrenner 近似值と弾性論放 密解との比較 (長さ係数 $\lambda=5$, 粘着接面の場合)

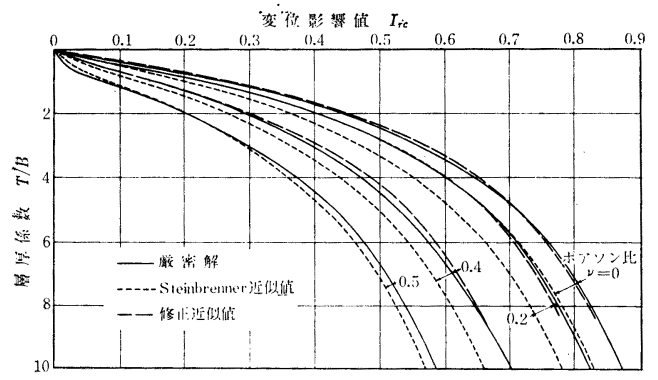

ここに, $\delta_{B}=T / B$

この近似式と厳密解の值を $\lambda=5$ の場合に対して示し てみると, 図一7 のようになる。すなわちポアソン比 0.5 のときはかなりよく近似した值を与えているが，ポ アソン比が小さくなると近似解は少しく小さい值を与え ることがわかる。誤差は条件によって異なるが常に 1 割 以下とみなせる。もし厳密解をさらによく近似計算しよ うとすれば， $\delta_{B}$ の代わりにつぎのような等価層厚係数 $\delta_{B}{ }^{\prime}$ でおきかえるとよい。すなわち,

$$
\delta_{B}{ }^{\prime}=n \delta_{B}
$$

ここに, $n$ は等価係数で, $\nu=0 \sim 0.4$ に対し, 1.2 が 適当である。

\section{3. 二層弾性体（硬地盤上土層）の表面変位}

前章の剛盤上弹性体に対しては変位影響值を用いて考 察したが, 二層弾性体に対しては, 以下に定義されるよ うな変位係数 $F$ で考察するのが習慣的であり, 便利で もある。

$$
\begin{aligned}
& F_{c o}=w_{c o} /\left[\frac{2\left(1-\nu_{2}^{2}\right)}{E_{2}} p a\right] \\
& F_{c e}=w_{c e} /\left[\frac{2\left(1-\nu_{2}^{2}\right)}{E_{2}} p a\right]
\end{aligned}
$$

ここに, $F_{c o}$ : 二層弾性体の円形等分布荷重中心点に 対する変位係数

$w_{c o}:$ 二層弾性体の円形等分布荷重中心点に 対する変位

$F_{c e}$ : 二層弾性体の円形等分布荷重縁部に対 する変位係数

$w_{c e}$ : 二層弾性体の円形等分布荷重縁部に対 する変位係数

$E_{2}:$ 下層の弾性係数

$\nu_{2}:$ 下層のポアソン比

舗装構造のように上層が下層より硬い場合の二層弾性 体の変位係数については Burmister ${ }^{11)}$ が広範に計算して おり，剛盤上弾性体については Burmister ${ }^{8)}$ と筆者ら が広範に計算した。しかしこの章で扱おうとする硬地盤 上土層のような二層弾性体問題は $\mathrm{Kirk}^{12)}$ が $F_{c o}$ に対
し $E_{1} / E_{2}=0.2$ の場合を計算した以外には見あたらな い。そこで筆者らは, $\nu_{1}=\nu_{2}=0.5$ で $E_{1} / E_{2}=0.01,0.1$, $0.2,0.5$ の場合の $F_{c o}$ と $F_{c e}$ を IBM 7094 にて計算 し，その結果を図一8に示した。

この二層弾性体の場合を剛盤上弾性体の場合と比較す るためにはつぎに定義する修正変位係数 $F_{c o}{ }^{\prime}, F_{c e}{ }^{\prime}$ を用 いるほうがよい。

$$
\left.\begin{array}{rl}
F_{c o}{ }^{\prime} & =w_{c o} /\left[\frac{2\left(1-\nu_{1}^{2}\right)}{E_{1}} p a\right] \\
& =\frac{E_{1}\left(1-\nu_{2}^{2}\right)}{E_{2}\left(1-\nu_{1}^{2}\right)} F_{c o} \\
F_{c e}{ }^{\prime} & =w_{c e} /\left[\frac{2\left(1-\nu_{1}{ }^{2}\right)}{E_{1}} p a\right] \\
& =\frac{E_{1}\left(1-\nu_{2}^{2}\right)}{E_{2}\left(1-\nu_{1}^{2}\right)} F_{c e}
\end{array}\right\}
$$

図一8 円形等分布荷重のもとでの二届弾性体の 荷重面中央点および悢部での変位係数 $\left(\boldsymbol{F}_{c o}\right.$ および $\left.\boldsymbol{F}_{c e}\right)$ と局军你数との関係 ( $\nu_{1}=\nu_{2}=0.5$, 粘着接面の場合)

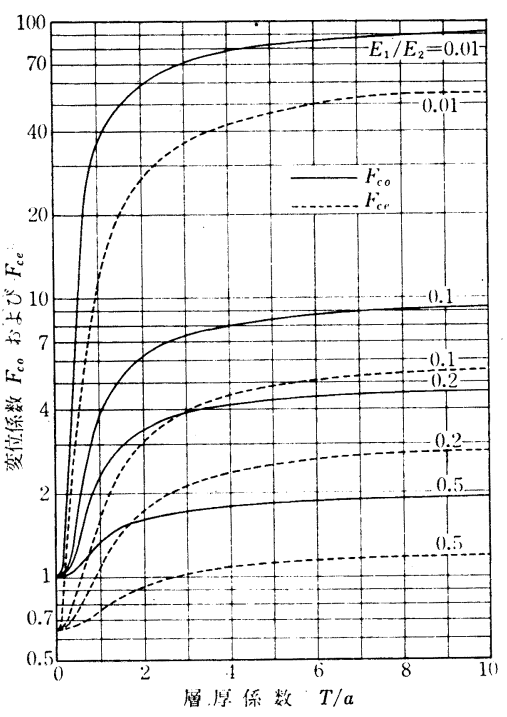

図一9 円形等分布荷亶のもとでの二俨弾性体の 荷重面中央部での修正变位係数 $\boldsymbol{F}_{c o}{ }^{\prime}$ と 用厓你数との関係 $\left(\nu_{1}=\nu_{2}=0.5\right.$, 粘着接面の場合)

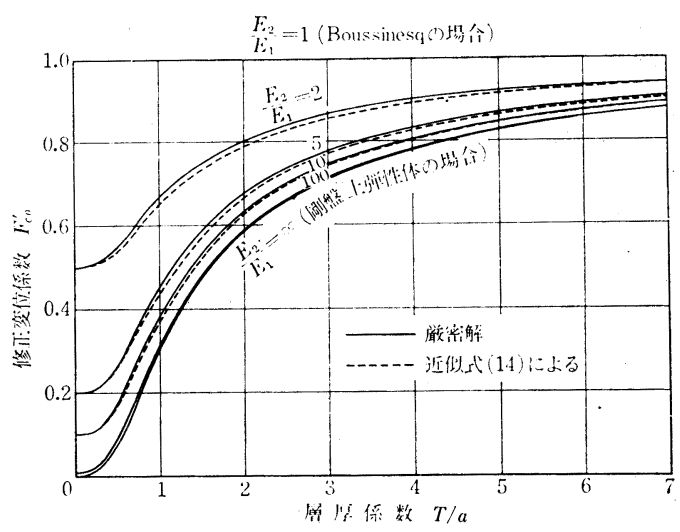


図一10 円形等分布荷臬のもとでの二虽弾性体の 荷重面爆部での修正変位係数 $\boldsymbol{F}_{c e}{ }^{\prime}$ と届 厚係数との関係

$\left(\nu_{1}=\nu_{2}=0.5\right.$, 粘着接面の場合 $)$

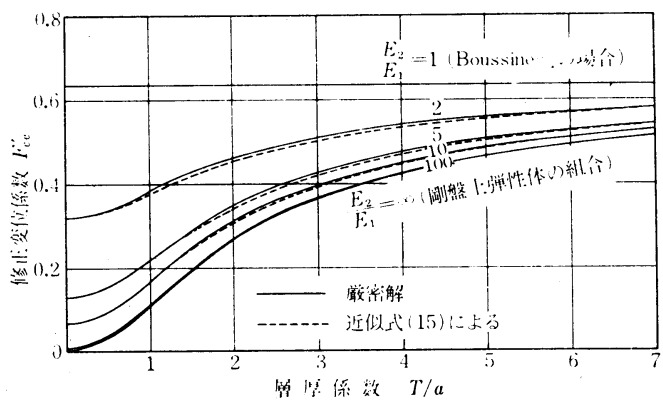

これら二層弾性体の $F_{c o}{ }^{\prime}, F_{c e}{ }^{\prime}$ を剛盤上弾性体の場合 およびBoussinesq の場合と比較して示したのが, 図一9 および図一10 である。

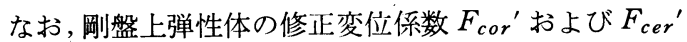
にもとづいて任意の二層弾性体の修正変位係数 $F_{c o}{ }^{\prime} お$ よび $F_{c e} e^{\prime}$ を近似的に次式で求めることができる。

$$
\begin{aligned}
& F_{c o^{\prime}}=F_{c o r^{\prime}}+\frac{E_{1}}{E_{2}}\left(1-F_{c o r^{\prime}}\right) \cdots \cdots \\
& F_{c e^{\prime}}=F_{c e r}{ }^{\prime}+\frac{E_{1}}{E_{2}}\left(0.637-F_{c e r}{ }^{\prime}\right) \cdots
\end{aligned}
$$

$$
\text { ここに, }
$$

$$
\begin{aligned}
& F_{c o r}{ }^{\prime}=\frac{1}{2\left(1-\nu_{1}^{2}\right)} I_{c o} \\
& F_{c e r}{ }^{\prime}=\frac{1}{2\left(1-\nu_{1}^{2}\right)} I_{c e}
\end{aligned}
$$

式 (14), 式 (15) で計算した修正変位係数も比較のた めに図一9, 図一10に記入して示した。

\section{4. 結言}

この報文の結果と結論を要約すればつぎのようであ る。

（1）岩盤上土層表面の弾性的沈下量を推定する目的 をもって, 剛盤上弾性体表酒に円形等分布荷重, 帯状等 分布荷重, 長方形等分布荷重などが加わったときの弾性 変位量を変位影響值のかたちで，弾性理論にもと一゙き数 值計算した。

（2） Steinbrenner の近似解 と弾性論厳密解の比較 を行なったが,両者の相異は概して1割以内とみなせる。 $\nu=0.5$ では Steinbrenner 式の近似度はよいが, ポアソ ン比が 0 から 0.4 の範囲で近似度をさらによくするため には, Steinbrenner 式中の $\delta_{B}$ の代わりに $\delta_{B}{ }^{\prime}=1.2 \delta_{B}$ を用いるとよい。

（3）上層弾性体のポアソン比が 0.5 に近い場合には 剛盤上弾性体の変位量は接面の状態およびポアソン比の 相異に大きい影響をうけるが，ポアソン比が 0 に近くな ると, 二層接面の状態, ポアソン比の相違の影響はほと んどなくなる。
（4）二層弾性体（硬地盤上土層）の各層のポアソン 比を 0.5 と仮定したときの円形等分布荷重面の中心と縁 部における表面変位量を変位係数または修正変位係数の 形で計算した。また剛盤上弾性体の変位影響值にもとゔ き,一般の二層弾性体の修正変位係数を近似計算する方 法を示した。

なお,この研究は植下が文部省在外研究員として, 名 古屋大学加 Nova Scotia Technical College に派遣 され, National Research Council of Canada $の$ PostDoctoral Research Fellowship を得て, Meyerhof 研 究室で行なったものである。この出張研究をご援助下さ った各関係方面に感謝の意を表する次第である。

\section{参考文 献}

1) Boussinesq, J. : “Applications des Potentials", à l'Étude de l'Équilibre et du Mouvement des Solides Élastiques, Paris, Gauthier-Villard, 1885. •

2) Filon, L.N. G. : Phil. Trans. Royal Society, Series A, Vol. 201. 1903, p. 107.

3) Melan, E. : Die Druckverteilung durch eine elastische Schicht", Beton u. Eisen, Vol. 18, 1919, pp. 83-85.

4) Marguerre, K. : "Druckverteilung durch eine elastische Schicht auf starrer rauher Unterlage", Ingenieur-Archiv, Vol. 2, 1931, pp. 108-117.

5) Biot, M.A. : Effect of Certain Discontinuities on the Pressure Distribution in a Loaded Soil", Physics, Vol. 6, 1935, pp. 367-375.

6) Pickett, G. : "Stress Distribution in a Loaded Soil with Some Rigid Boundaries", Proc. H.R.B., Vol. 18, Part 2, 1938, pp. 35-48.

7) Steinbrenner, W. : "Tafeln zur Zetzungsberechnung”, Die Strasse, Vol. 1, 1934, pp. 121-124.

8) Burmister, D.M. : "Stress and Displacement Characteristics of a Two-Layer Rigid Base Soil System: Influence Diagrams and Practical Application"' Proc. H.R.B., Vol. 35, 1956, pp, 773-814.

9) Mandel, J. : "Consolidation of Clay Layers", Proc. 4 th Int. Conf. Soil Mech. and Found. Eng., Vol. 1. 1957, pp. 360-363.

10) Sovinc, I. : "Stresses and Displacements in a Limited Layer of Uniform Thickness, resting on a Rigid Base, and subjected to an Uniformly Distributed Flexible Load of Rectangular Shape"' Proc. 5 th Int. Conf. Soil Mech. and Found. Eng., Vol. 1, 1961, pp. 823-827.

11) Burmister, D.M. : "The Theory of Stresses and Displacements in Layered Systems and Application to the Design of Airport Runways" Proc. H.R.B., Vol. 23, 1943, pp. 126-148.

12) Kirk, J.M. : "Beregning of nedsynkningen i lagdelte systemer", Dansk Vejtidsskrift, Vol. 38, No. 12, 1961. pp. 294-296.

13）植下 協:「岩盤上土層表面の弾性的沈下について」, 第 1 回土質工学研究発表会講演集, 1966, 土質工学会, pp. $175 \sim 178$.

【付 記】本論文における計算のうち，円形等分布 荷重に対する変位影響值 $I$ および変位係数 $F$ を求める 理論および計算過程を一例として紹介する。 


\section{（1）計算に用いた座標系}

この論文で円形等分布荷重による表面変位を求めた地

\section{図一11岩盤上土屈のモデル}

（a）剛盤上弾性体の場合（b）二層弾性体の場合
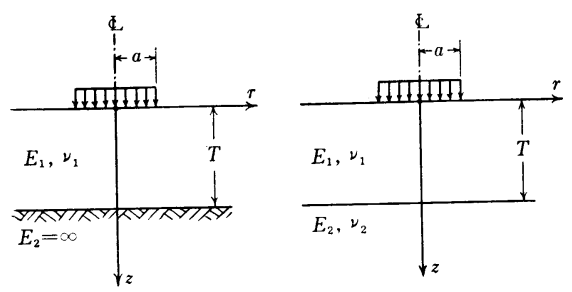

盤のモデルは，図一11 （a）に示す剛盤上弾性 体の場合と, 図一11 （b）に示す二層弾性体 の場合とである。この 問題は軸対称であるた め, 図一12 に示すよう な円筒座標で考え，原 点は地表面の荷重中心 点にとり, $z$ 点は下方 图一12坐標系

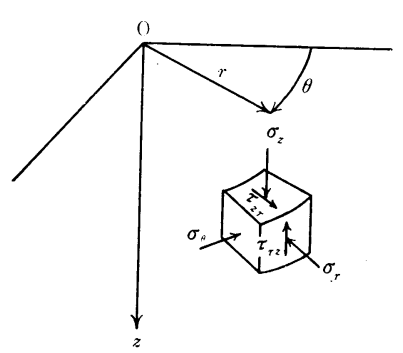
孝正とした。

\section{（2） つりあい方程式}

$$
\begin{aligned}
& \frac{\partial \sigma_{r}}{\partial r}+\frac{\sigma_{r}-\sigma_{\theta}}{r}+\frac{\partial \tau_{r z}}{\partial z}=0 \\
& \frac{\partial \tau_{r z}}{\partial r}+\frac{\tau_{r \boldsymbol{z}}}{r}+\frac{\partial \sigma_{z}}{\partial z}=0
\end{aligned}
$$

ここに, $\sigma_{r}=$ 半径方向の直応力 $\sigma_{B}=$ 円周方向の直応力

$\sigma_{z}=$ 鉛直方向の直応力

$\tau_{r z}=$ 円周に沿い鉛直方向に働くせん断応力

これらの応力は土質力学における習慣に従い, 圧縮応 力を正とした。各応力の正方向を 図一12 の知印で示し てある。

\section{(3) 適合条件式}

$$
\begin{aligned}
\nabla^{4} \phi_{j} & =0 \\
こ こ に, \nabla^{2} & =\left(\frac{\partial^{2}}{\partial r^{2}}+\frac{1}{r} \frac{\partial}{\partial r}+\frac{\partial^{2}}{\partial z^{2}}\right) \\
\phi_{j} & =j \text { 番目層内の応力関数 }
\end{aligned}
$$

\section{(4) 応力関数で表現した各応力}

$$
\begin{aligned}
& \sigma_{z j}=\frac{\partial}{\partial z}\left[\frac{\partial^{2} \phi_{j}}{\partial z^{2}}-\left(2-\nu_{j}\right) \nabla^{2} \phi_{j}\right] \\
& \sigma_{r j}=\frac{\partial}{\partial z}\left[\frac{\partial^{2} \phi_{j}}{\partial r^{2}}-\nu_{j} \nabla^{2} \phi_{j}\right] \\
& \sigma_{\theta j}=\frac{\partial}{\partial z}\left[\frac{1}{r} \frac{\partial^{2} \phi_{j}}{\partial r^{2}}-\nu_{j} \nabla^{2} \phi_{j}\right]
\end{aligned}
$$

$$
\tau_{r z j}=\frac{\partial}{\partial r}\left[\frac{\partial^{2} \phi_{j}}{\partial z^{2}}-\left(1-\nu_{j}\right) \nabla^{2} \phi_{j}\right]
$$

ここに, $j$ は $j$ 番目層内の值であることを示す。

\section{（5）変位に関する式}

$$
\begin{aligned}
& w_{j}=\frac{1+\nu_{j}}{E_{j}}\left[2\left(1-\nu_{j}\right) \nabla^{2} \phi_{j}-\frac{\partial^{2} \phi_{j}}{\partial z^{2}}\right] \\
& u_{j}=-\frac{1+\nu_{j}}{E_{j}} \frac{\partial^{2} \phi_{j}}{\partial r \partial z}
\end{aligned}
$$

ここに, $w_{j}=j$ 番目層内のある点の鉛直変位 $u_{j}=j$ 番目層内のある点の半径方向変位 これらの変位は座標軸プラス方向を正とする。

\section{(6) 応力関数}

適合条件式を満足する応力関数はつぎのようなもので ある。

$$
\begin{aligned}
& \phi_{m j}= J_{0}(m \rho)\left[c_{j_{1}} \cosh m \zeta+c_{j_{2}} \sinh m \zeta\right. \\
&\left.+c_{j_{3}} \zeta \cosh m \zeta+c_{j_{4}} \sinh m \zeta\right] \\
& こ こ に, \quad \zeta=\frac{z}{T} \\
& \rho=\frac{r}{T} \\
& J_{0}=\text { 第 } 1 \text { 種 } 0 \text { 次のベッセル関数 } \\
& m=\text { 無次元のパラメーター } \\
& c_{j_{1}}, c_{j_{2}}, c_{j_{3}}, c_{j_{4}} \text { は } j \text { 番目層に対する積分定 }
\end{aligned}
$$

数で境界条件によって定まるものである。

\section{（7）境界条件}

(7-A) 地表（ $\zeta=0 ）$ における条件

(i) $\sigma_{z_{1}}=p \alpha \int_{0}^{\infty} J_{1}(m \alpha) J_{0}(m \rho) d \mathrm{~m}$

[Fourier-Hankel 変換]

$$
\begin{aligned}
& =\left\{\begin{array}{ll}
p & {[\alpha>\rho>0} \\
\frac{1}{2} p & {[\rho=\alpha>0 \text { に対し }]} \\
0 & {[\rho>\alpha>0}
\end{array}\right] \\
& =\int_{0}^{\infty} \sigma_{z m} d m
\end{aligned}
$$

ここに,

$$
\alpha=\frac{a}{T}
$$

$J_{1}=$ 第 1 種 1 次のベッセル関数

$\sigma_{z m}=p \alpha J_{1}(m \alpha) J_{0}(m \rho) \quad[\zeta=0$ に対し $]$

(ii) $\tau_{r z 1}=0$

(7-B) 二層接面 $(\zeta=1)$ における条件

(7-B-1) 剛盤上弾性体（粘着接面）の場合

(i) $w_{1}=0$ (岩盤を非圧縮性と仮定)

(ii) $u_{1}=0$ （弾性体と剛体とは接面で相対移動しな 、と仮定）

(7-B-2) 二層弹性体（粘着接面）の場合

(i) $w_{1}=w_{2}$

(ii) $u_{1}=u_{2}$ 
(iii) $\sigma_{z_{1}}=\sigma_{z 2}$

(iv) $\tau_{r z 1}=\tau_{r z 2}$

(7-C) 無限樑さ $(\zeta=\infty)$ における条件 (二層弾性体 の場合に対し)

(i) $\sigma_{z 2}=0$

(ii) $w_{2}=0$

(8) $c_{j_{1}}, c_{j_{2}}, \boldsymbol{c}_{j_{3}}, \boldsymbol{c}_{j_{4}}$ を決めるために用いた応力と 変位の式

$$
\begin{aligned}
& \sigma_{z m j}=\left[c_{j_{1}} \sinh m \zeta+c_{j_{2}} \cosh m \zeta\right. \\
& +c_{j_{3}}\left(\zeta \sinh m \zeta-\frac{1-2 \nu_{j}}{m} \cosh m \zeta\right) \\
& \left.+c_{j 4}\left(\zeta \cosh m \zeta-\frac{1-2 \nu_{j}}{m} \sinh m \zeta\right)\right] \\
& \times \frac{m^{3}}{T^{3}} J_{0}(m \rho) \\
& \tau_{r z m j}=-\left[c_{j_{1}} \cosh m \zeta+c_{j_{2}} \sinh m \zeta\right. \\
& +c_{j_{3}}\left(\zeta \cosh m \zeta+\frac{2 \nu_{j}}{m} \sinh m \zeta\right) \\
& \left.+c_{j_{4}}\left(\zeta \sinh m \zeta+\frac{2 \nu_{j}}{m} \cosh m \zeta\right)\right] \\
& \times \frac{m^{3}}{T^{3}} J_{1}(m \rho) \\
& w_{m j}=-\frac{1+\nu_{j}}{E_{j}}\left[c_{j_{1}} \cosh m \zeta+c_{j_{2}} \sinh m \zeta\right. \\
& +c_{j_{3}}\left(\zeta \cosh m \zeta-\frac{2-4 \nu_{j}}{m} \sinh m \zeta\right) \\
& \left.+c_{j_{4}}\left(\zeta \sinh m \zeta-\frac{2-4 \nu_{j}}{m} \cosh m \zeta\right)\right] \\
& \times \frac{m^{2}}{T^{2}} J_{0}(m \rho) \\
& u_{m j}=\frac{1+\nu_{j}}{E_{j}}\left[c_{j_{1}} \sinh m \zeta+c_{j_{2}} \cosh m \zeta\right. \\
& +c_{j_{3}}\left(\frac{1}{m} \cosh m \zeta+\zeta \sinh m \zeta\right) \\
& \left.+c_{j_{4}}\left(\frac{1}{m} \sinh m \zeta+\zeta \cosh m \zeta\right)\right] \\
& \times \frac{m^{2}}{T^{2}} J_{1}(m \rho) \\
& \text { ここに, } \sigma_{z j}=\int_{0}^{\infty} \sigma_{z m j} d m \text {, } \\
& \tau_{r z j}=\int_{0}^{\infty} \tau_{r z m j} d m,
\end{aligned}
$$

$$
\begin{aligned}
w_{j} & =\int_{0}^{\infty} w_{m j} d m \\
u_{j} & =\int_{0}^{\infty} u_{m j} d m
\end{aligned}
$$

\section{（9）計算した式}

$$
\begin{aligned}
w_{c o}= & -\frac{1+\nu_{1}}{E_{1}} \int_{0}^{\infty}\left[c_{j_{1}}-c_{j_{4}} \frac{2-4 \nu_{j}}{m}\right] \frac{m^{2}}{T^{2}} d m \\
w_{c e}= & -\frac{1+\nu_{1}}{E_{1}} \int_{0}^{\infty}\left[c_{j_{1}}-c_{j_{4}} \frac{2-4 \nu_{j}}{m}\right] \\
& \times \frac{m^{2}}{T^{2}} J_{0}(m \alpha) d m
\end{aligned}
$$

これらの式を次式に代入し， $I$ または $F$ の值として計 算した。

変位影響值 :

$$
\begin{aligned}
& I_{c o}=w_{c o} / \frac{p}{E} a \\
& I_{c e}=w_{c e} / \frac{p}{E} a
\end{aligned}
$$

変位係数 :

$$
\begin{aligned}
& F_{c o}=w_{c o} /\left[\frac{2\left(1-\nu_{2}{ }^{2}\right)}{E_{2}} p a\right] \\
& F_{c e}=w_{c e} /\left[\frac{2\left(1-\nu_{2}^{2}\right)}{E_{2}} p a\right]
\end{aligned}
$$

\section{（10）計算の実施手順}

上述の式により $I$ および $F$ を求めるには無限範囲の 数值積分を行なわねばならないが，その方法としては $J_{1}(m \alpha)$ がゼロとなる区間ごとに Gauss の 8 点公式を 利用して区分求積してゆき，この数值積分をつぎの関倸 が満たされるまで続けた。

\section{$\frac{\text { (第 } N \text { 番目区間の積分による増分) }}{\text { (第 } N \text { 番目区間までの総積分值) }}<0.001$}

しかし，収れんのわるい場合は上記方法による100区 間の積分後も上式の関係が満たされない場合があった。 しかしここに述べる積分法によると, 積分值は各区間ご とに最終值の上下に振動しつつ収れんする性質をもって おり, 最終 2 回分の答の平均により十分精度の高い答の 得られることがわかっていたので, 100 区間の積分を行 なった場合は, 上式の関係とは無関係に計算を打ち切っ た。

(1967.1.12 - 受付) 